\title{
Institutions for survival: The Shargorod ghetto during the Holocaust in Romanian Transnistria
}

\author{
Iemima D. Ploscariu* \\ Dublin City University, Dublin, Ireland \\ *Corresponding author. Email: iploscariu@gmail.com
}

\begin{abstract}
In 1941, thousands of Jews from the regions of Bukovina and Bessarabia were deported to ghettos and camps in Romanian-occupied Transnistria to join local Ukranian Jews and other deportees. This article is a case study of the Shargorod ghetto, one of the largest ghettos in Transnistria, that reveals how individuals interned there, and in similar ghettos, survived despite their different social, economic, and cultural backgrounds. An examination based on regions allows for a better understanding of the diverse Jewish communities in Romania and how these differences influenced the lives of local Jews and deportees during the formidable years in Shargorod. Their major successes, as well as their failures, present a picture of entangled community identity in the face of disease, starvation, and forced labor. The survival of the Jewish population of Shargorod from 1941 to 1944 is analyzed through the selection of leadership by the ghetto inhabitants (specifically, Meier Teich's role as ghetto leader), the entrepreneurial actions and aid that arose, and the format and agenda adopted by the ghetto's cultural institutions.
\end{abstract}

Keywords: Shargorod; Holocaust; Jewish ghetto; Romania; Transnistria

As a result of the treaties of World War I, Romania doubled in size, both geographically and demographically. The Regat (the principalities of Wallachia and Moldova), Transylvania, Bessarabia, and Bukovina were among the territories that comprised Greater Romania. ${ }^{1}$ Each of these regions was distinctly unique in its blend of traditions, languages, and social customs; and each had a vibrant Jewish population of vital social, political, and economic importance (Janowski et al 2005). However, Romanian Jews differed as much, if not more, than the ethnic Romanians in each of the country's regions.

The newly annexed region of Bessarabia in the east had a Jewish population of seven percent in the 1930 census. These communities, previously under Tsarist rule, were traditionally involved in agriculture and experienced more restrictions regarding property ownership, trade, and cultural institutions than those in Bukovina. Bessarabia was also regarded as a "breeding ground" for modern Jewish politics, with a significant number of Zionists as well as communist groups (Vago 1994, 31). Exaggerated claims of Bessarabian Jews supporting Soviet Russia was a reason Antonescu enacted stricter measures to eradicate their communities during the war. Bukovina, along with Banat and Transylvania, were zones of multi-ethnic contact between Germans, Hungarians, Jews, Roma, Romanians, and Ukrainians, among others. These regions, in contrast to Bessarabia, were previously part of the Austro-Hungarian Empire, which provided a greater degree of political and economic freedom for minorities and, unlike Romania, had granted citizenship rights to all Jews. The Jewish community in 1930 reached eleven percent of Bukovina's population and Czernowitz, the region's capitol, depended heavily on Jewish individuals in the political, economic, and social spheres of the city. Statistics from 1930 show Jews held 79.3\% 


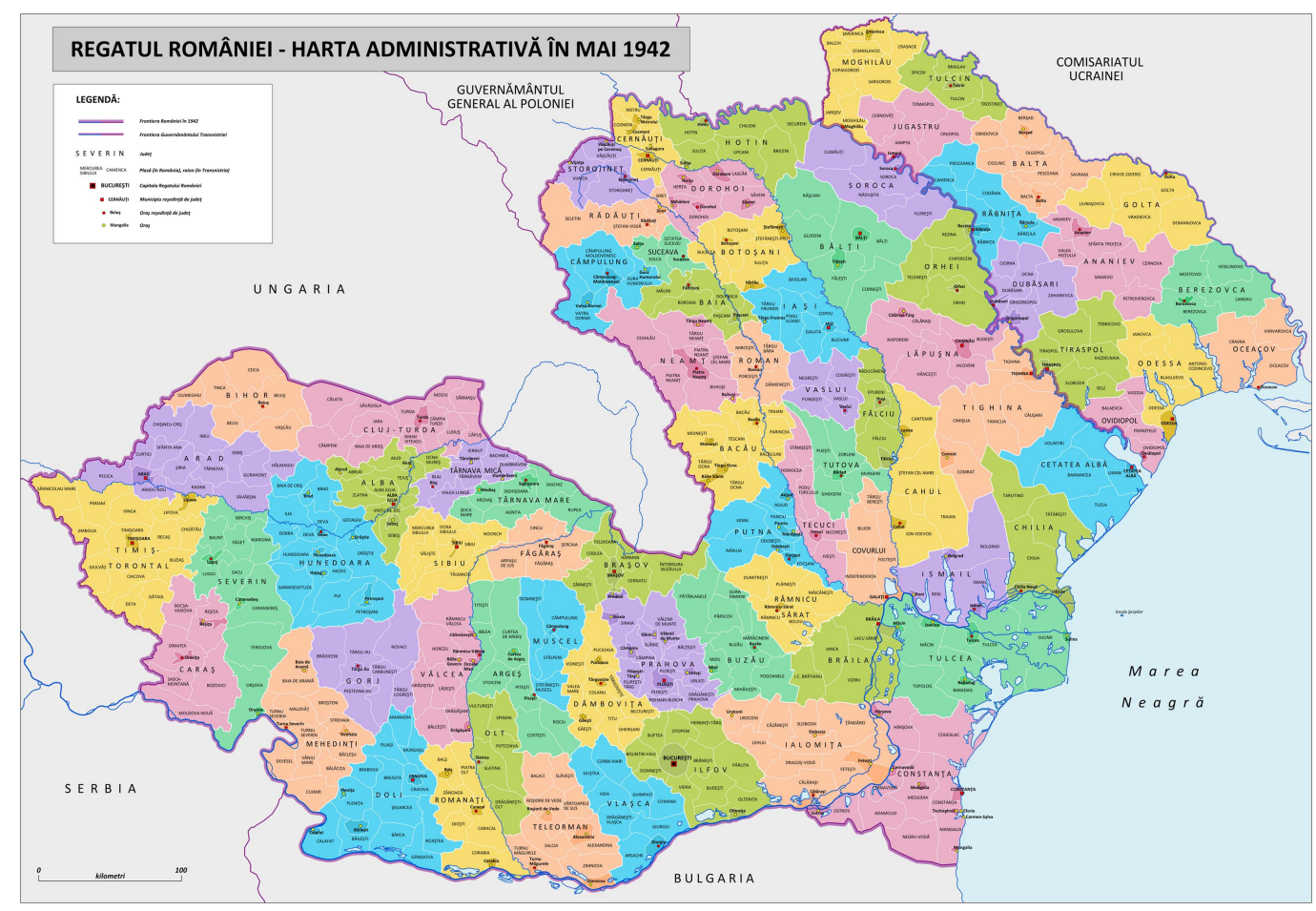

Figure 1. Romania including the regions of Bukovina, Bessarabia, and Transnistria, 1942 (Andrein 2011).

of commerce, $66.4 \%$ of credit, and $35.3 \%$ of industry in Bukovina, similar to figures in Bessarabia, where Jews held $77.4 \%$ of commerce, $54.8 \%$ of credit, and $42.3 \%$ of industry (Solonari 2010, 222).

Jewish communities in Romanian lands experienced difficulties throughout the interwar years as ultra-nationalist politicians sought to deprive them of their rights. Various influential Jewish representatives, such as lawyer Wilhelm Filderman, attempted to offer protection to Romanian Jews no matter their residence and place of origin. ${ }^{2}$ In June 1940, the Soviet Union conquered Bessarabia and Northern Bukovina, separating the Jewish communities there from the rest of Romania until Romanian forces reconquered the regions in July 1941. The year of Soviet occupation also had a weakening affect on the Jewish communities in these territories. Many Jewish institutions were closed and leaders and intellectuals exiled (Levin 1995, 37-39). The return of Bessarabia and Northern Bukovina to Romanian authority in 1941 only worsened the situation of these communities, where they were now viewed by Romanian leader Marshal Ion Antonescu as former Soviet citizens and communist sympathizers.

Less than two months later on August 30, 1941, the Nazi-German government ceded the region of Transnistria-the land between the Dniester River and the Bug River-to its Romanian ally through the signing of the Tighina Agreement (Ofer 2009, 32; see Figure 1). ${ }^{3}$ Prior to German occupation, Transnistria was part of the Soviet Union, where great effort was placed toward integrating Jews into Soviet society and presenting anti-Semitism as archaic and bourgeois (Dumitru 2016, 93-138). Nevertheless, leaders had been purged during the interwar period and Jewish institutions shut down, such that the German occupational forces often appointed any Jewish men, many without leadership experience, to head the newly formed wartime Jewish councils (Altshuler 2012, 252-253; Arad 2009, 118). Unlike Romania's other territories, Transnistria did not have a large ethnic Romanian population nor was it of great political or sentimental significance. The land became for Antonescu a dumping ground for Romania's Jews. 


\section{Shargorod}

Between 1940 and 1945, Jews deported from Bukovina, Bessarabia, and the Regat, as well as local Transnistrian Jews, were lumped together and forced to depend on one another for survival. One such place of Jewish conglomeration in Transnistria was the Shargorod ghetto. I use the more common spelling of Shargorod for the town; variants include Șargorod, Sargorot, and Sharhorod. The town of Shargorod can be studied as a microcosm to better understand what occurred in the majority of ghettos in Transnistria. ${ }^{4}$ Shargorod had been a thriving shtetl in the late 18th and early 19th century: an important center of trade as well as Jewish culture and religious life in the Podolia region (Petrovsky-Shtern 2014). During the Soviet years, a local stated, "If there were any expressions of anti-Semitism before the war, they would elicit nothing but surprise or bewilderment, so strange they would seem" (Ivankovitser 2002). The changing politics of the regiongrowing anti-Semitism under tsarist rule and then Sovietization after 1917-transformed Jewish life in Shargorod and the Jewish character of the town.

In November 1941, about 5,000 Jewish deportees from Bessarabia and Bukovina arrived in Shargorod. These were added to the approximately 2,000 remaining local Jews (Teich 1958, 232; Inspectoratul General al Jandarmeriei, Direcțiunea Siguranței și Ord. Publice, September 1, 1943, in Carp 1996, 207, 334, 457). ${ }^{5}$ The majority of deportees originated from the Southern Bukovinan city of Suceava with groups from Căuşeni, Vatra Dornei, Câmpulung, Vijnița, Czernowitz, and Dorohoi. Deportees in general tried to reach fellow deportees from their hometowns. Jews from Șiret (Southern Bukovina) bribed officials to reach the Djurin ghetto where their neighbors had been sent (Shachan 1996, 187). In Moghilev there were many from Rădăuți or Czernowitz, while the Jews of Suceava largely made it to Shargorod. However, there was always a mix of deportees and locals within the ghetto which produced tension, exacerbating difficulties while at other times ameliorating them.

How, then, did the individuals interred in ghettos from different social, economic, and political backgrounds focus their tactics for survival? Jewish locals and deportees in Shargorod, one of the largest ghettos in Romanian-occupied Transnistria, were faced with overcoming the limitations of regional loyalties or identities, and redefining their notions of belonging through building institutions that would lead to survival for a portion of the ghetto inhabitants.

By identity, I refer to the loyalty toward certain ideas, claims to ancestry, and adherence to a system of mores that an individual or group internalizes, as well as the characteristics they exhibit, which enable others to recognize the individual or group (Rotenstreich 1993, 50). Historian Leon J. Goldstein reveals the complexities of Jewish identity or identities-a glimpse of what Jews faced in Shargorod and in other ghettos and camps during the Holocaust:

"When we realize how dispersed over natural and social space the Jewish people are, how differently Jews are affected by social, cultural, and intellectual elements, the variability in their conceptions of themselves is hardly to be wondered at. Even within the same highly complex societies, different Jews are affected by different sets of circumstances, and so a variety of different kinds of reshaping occurs. There is, to be sure, a sense of awareness, the recognition that, for better or for worse, all are Jews, the understanding of which is so variable as to be dazzling" (Goldstein 1993, 90). Jewish communities in the territories under Romanian rule provide a great example of the reshaping mentioned above.

This microstudy of the Shargorod ghetto provides a "thick description" of this particular ghetto and thus contributes to the study of the Holocaust in Romania and Holocaust studies in general. When possible, the situation in Shargorod is compared with that of other Transnistrian or Nazi-occupied ghettos to provide a wider historical context. The article uses a majority of published sources, including Benjamin M. Grilj, Sergij Osatschuk, and Dmytro Zhmundyljak's 2013 collection of wartime letters from Transnistrian deportees, in an attempt to understand the fierce struggle of Shargorod's victims and survivors and to open the field to more research on the topic of regional identity in Romania and across Europe. The methods of survival in Shargorod 
are best analyzed through the ghetto inhabitants' selection of leadership, the entrepreneurial and aid actions that arose, and the format and agenda adopted by the ghetto cultural institutions.

\section{Choosing leadership}

Establishing something akin to the kahals of former Jewish communities was not only a necessity for cohesion and efficiency, but also a requirement by the occupying Romanian and German powers. However, choosing a committee simultaneously protected and tore down the ghetto communities. The regions' different histories of Tsarist/Soviet, Romanian, and Austrian rule created communities with varying ideologies, traditions, economies, and governing and administrative styles. Prior to such issues of organization was the burden of survival. Ideal leaders, whether appointed by the state or self-appointed, had to be aware of the desperate situation of all Jews.

Meier Teich, who would become the committee leader of the Shargorod ghetto, described the arrival of his group in the crowded transit ghetto of Atachi, en route to Transnistria, as a sign of impending doom for the Jews already in the town. These Jews would be deported to the work camps across the Dniester to make room for even more arrivals. Teich wrote that the previous groups considered his party their enemies despite their similar plight (Carp 1996, 323). ${ }^{6}$ It was difficult to build strong and fair leadership in such hostile and uncertain situations. This carried over into the new settlements as poverty-stricken local Jews had to make room in their ghettos for beleaguered deportees.

Strong leadership was vital for the survival of both groups: local and deportee. Vadim Altskan's analysis of the Zhmerinka ghetto reveals a conglomeration of Jewish communities similar to the situation in Shargorod and most of the other Transnistrian ghettos. The Romanian Jewish deportees provided leaders who could interact with the occupying authorities due to their linguistic skills and their Romanian administrative and economic savvy. However, the local Ukrainian Jews knew the physical and social terrain of Shargorod. They had contacts with former neighbors and knew where to gain access to much needed resources, such as food and clothing (Altskan 2012, 12; Dumitru 2009, 43). Shared knowledge of Yiddish enabled ghetto residents to communicate among themselves, but this did not always mean rapport, as each regional group had different priorities and opinions. Many Transnistrian Jews may have only known Ukrainian or Russian, making communication more difficult.

In Shargorod, as in many of the other Transnistrian ghettos, it was the deportees from Bukovina who took leadership positions. These communities came by train and were often accompanied by their leaders along with some possessions, unlike the Bessarabian Jews. Priority was placed on a leader who could speak to the authorities in German or Romanian. The Shargorod County governor initially appointed Max Rosenrauch, from Suceava, as chairman of the ghetto. Moshe Katz from Rădăuți was assigned as his deputy. They were described as having the trust and admiration of the deportees. However, the representatives of the different community councils within the ghetto soon reached a consensus to form a central council composed of 25 delegates from among the deportee communities, including four Jewish locals. On November 17, 1941, these appointed Meier Teich as chairman and Abraham Reicher as deputy, with an inner council of eight men (Berthold Sponder Testimony, 27/PKR, Yad Vashem, in Shachan 1996, 236).

Teich was experienced in dealing with the Romanian authorities due to his previous position as president of a cooperative in Suceava and as former chairman of the Suceava Jewish Council ("Rumanian Jews," July 15, 1943, The Canadian Jewish Review, 7; Arhivele Nationale ale Romaniei, Bucharest, Romania, County Directory Suceava; 425, fond 4, inventory 4 and 387, folder 14/1937). Teich also had ties to international Jewish communities (Resolutions of the 16th Zionist Conference 1930, 69). In his analysis of the ghetto's self-administration, Teich claimed that Bucharest lawyer and advocate Wilhelm Filderman also supported him by sending a 
telegram to local Jews in Mogilev, instructing them to assist Teich (Teich 1958, 227). The election of leadership in Shargorod seemed to have occurred smoothly.

By contrast, in the Zhmerinka ghetto, clear animosity existed between Berl Ochakovskiy, the former local Ukrainian Jewish head of the ghetto labor department, and new leader Adolph Herschmann, a deportee from Czernowitz. Their disagreement led to the death of Ochakovskiy (Altskan 2012, 15). Teich's appointment showed that the inhabitants of Shargorod took initiative to choose their own leader rather than the one chosen by the Romanian authorities, and they did so within days after the arrival of the deportees. Teich claimed that the directors of the provisional Jewish community (the Obcina), which included two Bessarabian deportees, received him warmly on his arrival in Shargorod and sought to assist him in any way possible. It was at their initiative that Teich took advantage of the tension between the Ukrainian and the Romanian authorities in the town to the benefit of the ghetto residents. Teich must have also had help from local leadership to draw up for the authorities his authorization as the new ghetto head, written in Ukrainian (and Romanian; Teich 1958, 229). Unfortunately, there is little evidence from local Jews on their opinion of the leadership selection process. Bukovina Jews remained, as in most Transnistrian ghettos, at the forefront of ghetto organization, but valuable information continued to come from the Jewish locals.

An important criticism of Teich was that his ghetto council was composed of members with Suceava origins and, similarly, those from Suceava mostly received clerical jobs rather than manual labor (Deletant 2005, 26). The same thing occurred in Mogilev and other ghettos. However, according to Marusia Cirstea's archival research, Teich was beaten by Jewish residents on his return to Suceava because of "abusive and inhuman treatment" of fellow Suceavans in the Shargorod ghetto (Cîrstea 2011, 447; Arhivele Nationale Istorice Centrale, Bucharest, Romania, fond Directia Generala a Poliției, dosar 4/1946, Buletinul Informative al Direcției Generale a Poliției, nr. 160, 11 noiembrie 1946). The identity of the attackers and a description of the abusive treatment claimed are not provided. The strongest complaints against Teich, likely concerning the issue of forced labor, seemed to come from Bukovinians and, specifically, fellow Suceava Jews rather than from the locals. Zechariah Pitaru, a deportee from Dorohoi, was another opponent of Teich for what he saw as favoritism toward southern Bukovina Jews and resentful for his son being sent to forced labor. Pitaru created his own Jewish committee and police force in nearby Capușterna, similar in structure to the organization in Sharogord (Tibon 2016a, 162-163, 168). Forced labor and the committee members who compiled such lists were a source of consternation in the ghetto community and of great controversy among survivors after the war.

Nevertheless, Teich's account provided a balanced analysis of Jewish leadership with its many nuances and circumstances, which faced similar problems across Nazi-occupied and Nazi-allied Europe. He admitted to strict regulations regarding forced labor selections and his denial of showing favoritism holds some truth if, as Cirstea argues, even some from his native Suceava found reasons to blame him. The following section will go into more detail on how ghetto leaders dealt with forced labor lists in Shargorod. It is important to note that unlike Zmerinka's Adolph Herschmann, Djurin's Max Rosenrauch, or even Mogilev's resourceful Siegfried Jagendorf, Teich sought to transcend regional loyalties. As an example, he put his own life in jeopardy in an attempt to save six Jews from Dorohoi and from Rădăuți caught outside permissible areas on the road between the ghettos of Shargorod and Djurin. On March 20, 1942, Teich, along with Leib Goldschläger, called for a just trial for Strul and Smil Ceauș from Dorohoi, and Marcus Rauchman, Simeon Goldenberg, Roza Goldenberg, and Mina Wainiș from Rădăuți, but they were seconds too late as the six were shot in the Polish cemetary of Shargorod. When he failed to reach the executioner, Sergeant Major Florian, in time, he asked for documentation to be provided regarding the process of indictment, arguing that more papers were involved in burying a horse a few days earlier (Teich, "Masacru la Sargorod," in Carp 1996, 350). Teich fought for his coreligionists, not only the ones from Suceava, even after their deaths, knowing that if such injustice went unaddressed it would encourage more impunity on the part of the gendarmes. 
The formation of the Shargorod Jewish police force further reveals the breaking of regional barriers in choosing leadership. Unlike the dreaded ghetto police in Lodz, Warsaw, Lublin, and Nowy Dwor, who collaborated ruthlessly with the Nazi regime, the Jewish police in Shargorod were often remembered with appreciation (Trunk 1972, 480, 492; Weiss 1979, 201-217, 228233). Initially set up for self-defense against local police, the Shargorod ghetto police was headed by Bruno Koch of Câmpulung, a former reserve officer in the Romanian army. It was comprised of seventeen men, including two Jewish locals. The ghetto police managed to stop the assaults committed by mostly young local Ukrainian townspeople and Romanian gendarmes and was soon called upon to settle internal disputes. By their efforts the Ukrainian municipal militia was disbanded, but they faced much initial abuse by gendarmes until their authority was accepted (Peninah-Faina Pollack, 03/1220/Peh, Yad Vashem, in Shachan 1996, 269; Teich 1958, 230-231).

The participation of ghetto policemen in the communist partisan movement, with the approval of Teich and Koch, made Shargorod an even more interesting case of deportee-local cooperation. By spring 1943, Teich and others helped hide partisan commanders and met secretly with a Russian general to gain his support should the ghetto be in danger of liquidation (Carp 1996, 290, 306; Shachan 1996, 362). Shargorod police and committee leaders took great risks in protecting partisans, among them many local Jews. In other ghettos, such as Bershad, leaders discovered to be in contact with partisans were shot (Teich 1958, 247). Despite the threat of death, Shargorod leaders bypassed regional loyalties to help the local Jewish partisans. The ghetto police sought to protect and provide justice regardless of a ghetto member's origin.

Meier Teich remains the central figure of the Shargorod ghetto. Analyzing his leadership reveals the difficulties that many in his position faced. It is telling however, that when the Russian NKVD units arrested him upon their reoccupation of the region, it was the outcry of Shargorod's united Jewish community that saved him from sharing the same fate of execution as Zmerinka ghetto's Adolph Herschmann (Vynokurova 2010, 26). Teich remains a controversial figure. Though the evidence shows that Shargorod's leadership was comprised mostly of deportees from Bukovina (perhaps as much as 21 out of 25 committee members), such a decision was likely reached with the approval of Jews both local and from Romania.

They seemed to agree that the Bukovinians were best suited for resolving issues of finagling through administrative barriers and of maintaining cordial relationships with Romanian, Ukrainian, and Russian authorities. Unfortunately, most accounts are from the point of view of the leading deportees, marginalizing the local Jewish voices. The following sections will attempt to bring them in as much as possible to reveal the establishment of other vital institutions in the ghetto.

\section{Making a livable ghetto: entrepreneur actions and aid}

On arrival, a majority of deportees recalled their impressions of Shargorod as a town with small, old, clay houses (Baruch 2017, 63-72). There were about 337 of these houses, poorly constructed and with little ventilation, according to the account of Marcu Rozen, who was deported to Shargorod from Dorohoi at age eleven (Rozen 2004, 8). Approximately 7,000 ghetto inhabitants (deportees and locals) had to house themselves in these. One Suceavan deportee wrote home that up to 20 people lived in a single room (Doc. 201, Grilj et al 2013, 979-983; Teich 1958, 232). ${ }^{7}$ During the first months, the deportees organized themselves according to place of origin, attracted to what was, naturally, more familiar.

The Jews from Suceava arrived with the most resources, and they were the first to set up a soup kitchen, a bakery, and a small store. However, these were for the exclusive use of deportees from Suceava. The Jews from Câmpulung managed to open a store and sold food at a low cost to fellow Câmpulung deportees. By contrast, those who came from Dorohoi, Vijnița, Vatra Dornei, and Czernowitz arrived in winter with few belongings and received very little initial support. The majority survived by eating potato peelings, similar to the situation in Kopaigorod and other 
Transnistrian ghettos, as described by survivor Ietti Leibovici from Vatra Dornei (Leibovici 2008). ${ }^{8}$ Survivor Zecharyah Petru recalled the heartbreaking story of a mother who sought aid for her starving daughter but was refused because the money sent to the council was to be used only for those from a specific community of origin (Zecharyah Petru, Yad Vashem in Shachan 1996, 251). In the Djurin ghetto, committee secretary Lipman Konstadt from Radauți condemned ghetto head Max Rosenrauch, from Suceava, for his refusal to give equal care to local Jews (Ofer 1996, 270-271; Ofer 2009, 38). Konstadt stands out among Bukovinian deportee leaders in Transnistria for his early support of locals and as an example of how difficult it was to create solidarity among the various Jewish deportee and local groups.

The last deportees to arrive in Shargoord on November 16, 1941 were the 900 Dorohoi Jews. Saved from almost certain death through the intervention of Shargorod's Ukrainian peasant women, the ghetto had little room for them (Carp 1996, 276, 334; Teich 1958, 231-232). A deportee from Rădăuți wrote in a personal letter dated November 1941 that the Dorohoi Jews were suffering worst among the ghetto inhabitants and that their community leaders back home should send them money. This is another example of ghetto inhabitants relying on exclusivist aid based on place of origins to survive. Every community was expected to fend for its own members (Tibon 2016b). However, the same letter described Teich as doing all he could for those from Dorohoi despite being the "leader of those from Suceava" (Doc. 194, Grilj et al 2013, 931).

Money was, in fact, sent to the Dorohoi Jews and to others, but it was often lost on the way (Iancu 2008, 345-351; Shachan 1996, 298). ${ }^{9}$ This left the Dorohoi deportees at the mercy of others. Simon Meer, from Suceava, but living with an aunt in Dorohoi when he was deported to Shargorod in November 1941, recalled the situation differently in a 2008 interview. He said that the Bucovinians in Shargorod worked with the gendarme commandant to move his group of around 500 Dorohoi deportees to the village of Capușterna in 1943 until repatriated to Romania (Meer 2008). By this time the danger from the Romanian and German armies and administration had subsided, making such a move a hygienic benefit for all. Historian Gali Tibon clarifies the reasons behind the move of Dorohoi deportees from Shargorod to Capușterna as in part initiated by a Dorohoi deportee (2016a, 162). Fellow ghetto dwellers continued to mention in their letters the particular plight of those from Dorohoi (Doc. 5, Grilj et al 2013, 58-63).

However, even within the same community of origin, not everyone benefitted equally. A deportee from Suceava wrote that those who came to Shargorod from Bukovina in the third transport with Teich were better off than his family, who came in the second transport and had lost much of their luggage due to the many stops made in other localities (Doc. 201, Grilj et al 2013, 979-983). Others remarked that, though they were happy to be surrounded by acquaintances, regrettably, people could not help each other, but instead had to look out for themselves (Doc. 124, Grilj et al 2013, 606-609). Those who did try to help found that some abused their charity. Gusta, at an unknown ghetto in Transnistria, wrote to relatives that she gave money to a fellow Jew from Radauți who returned soon after, claiming she was to give him 5,000 more Lei. She wrote to her family: "My darlings, nowadays, you shouldn't get too involved with other people because time has stopped people [from] being ashamed and made them think others are required to help them" (Doc. 189, Grilj et al 2013, 893). Even the tie of community origin was not strong enough to procure aid or was used to harass people into giving money. Identity in such cases did not surpass the individual's physical needs.

Some deportees recorded that they received more help from those outside of their communities of origin. In Mogilev, Ruth and Fritz wrote to their parents in Cernowitz that their acquaintances from home, living in the room adjacent to theirs in the ghetto, would have nothing to do with them. They said strangers were more willing to help them than their own family (Doc. 99, Grilj et al 2013, 470-474). Anna Dahl wrote that the people with whom she stayed in Mogilev (locals and fellow deportees) were nice and helpful (Doc. 156, Grilj et al 2013, 738-741). A Bessarabian deportee to Mogilev recalled that on their arrival they were met with two kinds of people. The Jews from Suceava and Rădăuți, who still had suitcases and clothes, either refused to 
let the Bessarabian Jews into their dewllings due to fear of disease or, the second type, took pity on them, fed, and clothed them (Shachan 1996, 188). In Djurin, the local rabbi, Hershel Karalnik, ensured the majority of deportees were placed in the homes of local Jews. One thousand were lodged in stables outside of town, but he provided them with blankets and other necessities (Shachan 1996, 280).

In Shargorod also, the local Jews were described as opening up their homes to the deportees. A deportee family in Shargorod wrote in early December 1941 that all deportees lived in homes of local Jews who had taken them in. Ichel Pogranichny, a local Shargorod survivor, recalled that deportees from Romania lived in their home, making it a total of 20 in the house (Doc. 213, Grilj et al 2013, 1067; Pogranichny, "I Witnessed It All," in Zabarko 2005, 209). Letters confiscated from couriers coming from Transnistria reveal that even non-Jewish locals took in Jews, despite the illegality. A deportee, likely from Câmpulung, wrote of staying with her child in the home of a local Christian woman (Doc. 118, Grilj et al 2013, 580-584). She may have had money or things to trade, which would more likely allow such a situation. It was, nevertheless, risky on the part of the local Ukrainian woman. Local Jews often had no choice but to house the deportees since there was limited housing in the ghetto. However, there was seldom evidence of refusal or hostility on their part.

The different interactions described above show that strict isolationism by region of origin, as originally intended, was not sustainable. The Jews in the Shargorod ghetto first attempted to dismiss regional barriers for hygienic reasons. Various letters and survivors mentioned that there were no toilets in Shargorod. The new committee organized the construction of six public bathrooms. Teich wrote that there was tension with the locals regarding this because they thought energy and resources were better used elsewhere (Doc. 201, Grilj et al 2013, 983; Carp 1996, 334). Faina Vynokurova, in her study of the Bukovinian Jews in Transnistria, argues that they taught the local Jews the organization of a daily routine, observance and presevation of religious traditions, as well as craftsman skills, things lost during the two decades of Soviet propaganda $\left(2010,23\right.$; Rechter in Cohen et al 2010, 211). ${ }^{10}$ However, firsthand accounts show a sharing of resources and skills, though the Bukovinians indeed had more at their disposal due to their previous financial state and the nature of their deportations.

By working together, and for the benefit of the new community, an electrical plant was set up in Shargorod and some local factories reopened. The dirt roads were turned into cobblestone streets and cleaned daily (Carp 1996, 294; Teich 1958, 235, 240). The issue of forced labor lists (and lists in general), a painful subject in Holocaust studies due to the controversy regarding ghetto leadership, seemed to have been dealt with fairly in Shargorod. Testimonies of local Jewish survivors reveal that in some ghettos they were the first listed for forced labor across the Bug River because they did not have leaders to intercede for them as had the deportees (Ofer 1996, 252).

More research needs to be done on corroborating Teich's testimony, but evidence presented earlier in the article, regarding Suceavans on labor lists, point to a more impartial situation in Shargorod. "There was no favoritism before misery and death," claimed Teich. The council appointed a recruiting commission of three doctors known for their impartiality to say who would be listed for heavy labor. While lighter work could be paid off, and the funds would go to those willing to do the work in their place, hard labor could not be avoided (Teich 1958, 236239). Regardless of social status, wealth, or place of origin, those listed for hard labor had to comply due to the shortage of man power for the tasks assigned. In such cases there were no Bukovinian, Bessarabian, or Ukranian Jews, but stronger men who had to go work for the sake of the weaker community members.

Other important community insitutions were the soup kitchens, which ceased their exclusiveness and provided for the benefit of the needy regardless of place of origin. Filderman wrote to the Jewish ghetto leaders in Transnistria that "the kitchens are to be for the benefit of all who are needy regardless of whether they were born in the Rădăuți, Dorohoi, or Chișinău districts” 
(Filderman Archive File 45, 163, in Shachan 1996, 254). The Shargorod committee managed to organize the serving of 1,500 people per day and though the soup was far from nutritious, one survivor claimed it was worth the line nonetheless (Peninah Pollack, 03/1220/Peh; Moshe Dor, 93/1908, Yad Vashem, in Shachan 1996, 252). The thousands who could afford food were dependent on trade with the local Ukrainians and used the savvy of local Jews. A family from Suceava wrote they were lucky their landlady did not keep kosher so they could borrow her pots and plates. In what seems to be a sign of pure gratefulness they lamented that they did not have something to give to the landlady's 5-year-old daughter (Doc. 202, Grilj et al 2013, 997-1001). They found a point of commonality in their degree of assimilation. There were also observant Jews who managed to keep kosher, but more research is required to see how each group helped or hindered the other in Shargorod (Kermish 1986, 417; Baruch 2017). Food was the most important resource and procuring it for the vast amount of ghetto inhabitants meant appealing to fellow deportees of similar origin or breaking regional identity barriers; the two options were not exclusive.

Along with the soup kitchens, the ghetto inhabitants worked together to organize the running of the second and third most important institutions in the ghetto: the hospital and the orphanage. Overcrowding, the lack of nutritious food, and the inability to maintain good hygiene led to dysentery and jaundice, but the most dangerous disease was typhus. The Shargorod ghetto was among the ghettos most affected by the typhus epidemic, along with Bershad and Mogilev, during the winter of 1941 to 1942.

According to historian Jean Ancel, typhus killed 4,000 people in Shargorod. Teich writes of 1,500 victims of typhus, but he may not have included those Jews housed in villages nearby nor did he have the archival evidence that Ancel more recently procured (Ancel 2011, 400, 415; Carp 1996, 281; Teich 1958, 235). The committee organized a health service department along with a technical department, headed by deportees. The hospital for infectious diseases set up by the committee initially had 25 beds, but in February 1942, a second hospital was opened with 100 beds (Teich, "Excerpt from Monograph Composed for Romanian Social Institute, 15 January 1944," in Carp 1996, 334). Ghetto inhabitants worked together with committee supervision to block up contaminated streams and to fence off wells to avoid water contamination. They set up public toilets, shower and bath houses, and two disinfection ovens. Four hundred people would be disinfected daily. A soap factory was also organized, to manufacture soap for ghetto residents as well as to sell to the local Ukrainian population.

The epidemic died down in April due in large part to the dedicated doctors, all of whom were deportees, and to the aid dispersed by the committee's sanitation department (Baur 2014, 490491; Carp 1996, 282-283; Shachan 1996, 266-267; Teich 1958, 234). In Djurin, the ghetto similarly had doctors from Bukovina while in Oglopol there were two local doctors and one doctor from Bessarabia (Korber 2009). However, 12 of the 27 doctors in Shargorod died while treating typhus victims. Teich's son was also among the victims (Teich 1958, 232-234). Maria Averbuch, a local of Shargorod, who had 11 deportees join her house of five, described the locals as stronger than the deportees during the epidemic (Maria Averbuch, "We Were in Distress All the Time," in Zabarko 2005, 24).

The resilience of the locals and the resources and ingenuity of the deportees allowed for the strategy of containment described above. The ghetto was also divided into regions in May 1942, each region with its own doctor and trained staff. When an epidemic broke out in October, they were ready to deal with it. By 1943 the medicine arrived from the Autonomous Committee of Assistance in Bucharest, allowing the ghetto council to set up a pharmacy to provide medicine free of charge for the needy and at a small price for those who could afford it (Shachan 1996, 267).

The second issue that broke down regional loyalties and ensured survival was the need to care for the increasing number of orphans. A wagon load of salt, sent by the Autonomous Committee in Bucharest, was sold and the proceeds used to establish an orphanage in July 1942. 
The building housed 152 orphans and another 400 children with only one parent admitted later (Carp 1996, 300; Shachan 1996, 260; Teich 1958, 244). In the orphanage, the children were provided with food, clothes, schooling, and leisurely activities. Teich recounted the stories of several local Jewish orphans who came to Shargorod: Yosel Blech, Clara Moskal, and Leon Schuster from Kamenets, some from Kyiv, and others from different parts of Transnistria. Some of these children knew only Russian and the ghetto committee helped disguise them as Romanian Jewish children, teaching them critical phrases in Romanian. This way they could be taken to Romania during the early repatriations and would eventually immigrate to Israel (Teich 1958, 242-243). Even in some of the most difficult ghettos, like that of Domanevka, the Jewish council sought to help orphans in the Akmechetka camp by sending them part of their meager food supply in October 1942. Some families were willing to take in the 16 of 28 that survived and reached Domanevka (Shachan 1996, 253). The Jews who found themselves in Shargorod in the first few months of ghetto settlement were wary to help the "strange" Jews who were now their neighbors, but it seems this attitude changed or did not apply in the same way to the children. Teich and others went to dangerous lengths to protect refugee orphans from the authorities. Orphans like Moskal and Schuster, who joined the partisans, and those in Shargorod and other ghettos who supported them, defied regional labels. The camaraderie instilled during Soviet years may have helped Transnistria, and Shargorod, in particular, be a place where nationalities were more easily set aside. The leadership seems to have done whatever possible to protect as many as possible in their new community, regardless of regional identity. This was done not only through the institutions described above, but also through cultural initiatives.

\section{Maintaining culture}

The development of social and cultural activities provided further means of survival. Shargorod had a history of Jewish observance, associated with the Bal Shem Tov and Hassidism. The sacred place in the synagogue attributed to him was revered and protected by the deportees (Carp 1996, 8). The town had four synagogues, including the Great Synagogue, a large stone building built in 1589. These were turned into factories by the Soviet regime, but the Great Synagogue was reopened in the autumn of 1942. Once the typhus epidemic was under control, many in Shargorod returned to ritual observance. On the eve of Yom Kippur in 1942, the Jews gathered together for Kol Nidre, regardless of origin. A deportee from Câmpulung said a prayer in the memory of those who had died in Shargorod in pogroms of old (Weisbuch 2007).

Keeping the feast days and Sabbaths as best as they could was a form of resistance against their persecutors' demonization of Jewish culture, uniting the deportees and the local Jews (Ofer 2014, 387). Wedding, circumcisions, and bar mitzvahs were celebrated, and people met to pray during the week and on the Sabbath. In their letters, deportees mentioned the hope that the first day of Chanukkah brought for them but, unfortunately, did not reveal how they celebrated (Doc. 189, Grilj et al 2013, 893). ${ }^{11}$ Nevertheless, the stories and meaning behind the holidays seems to have given them hope. Due to the lack of nutrition, some recorded how they were permitted not to fast on Yom Kippur (Doc. 208, Grilj et al 2013, 1041). In Peciora, Transnistria, a survivor recalled the entire ghetto gathering to celebrate Rosh Hashanah, but on Yom Kippur there was a roundup of Jews for labor. The authorities tried to break community cohesion by conducting such aktions on holidays or on the Sabbath (R. Leshchinskaya, "These Were the First Living Jews They Met during the War," in Zabarko 2005, 162-163, 176; Korber 2009).

People nevertheless continued to celebrate. Samuil Roitberg's father, a local of Mogilev, gathered the ghetto dwellers for Rosh Hashanah and Yom Kippur with the help of a local priest in 1942 (Samuil Roitberg, "It Is Impossible to Dissolve the Whole Period of Living in the Ghetto," in Zabarko 2005, 252). In Olgopol, communal prayers were held in two synagogues to accommodate the entire ghetto population in an attempt to remove the authorities' suspicion of partisan collaboration-presenting themselves as observant Jews and not communists 
(Phillip Cohen, Yad Vashem interview, in Shachan 1996, 284). The Shargorod ghetto committee organized the repair and reopening of the communal baths, used also for ritual cleansing (Carp 1996, 294). The orphaned nephew of Mottel Beinstein, a Shargorod Jewish local, was taken in by the orphanage and celebrated his bar mitzvah (Teich 1958, 243). The encouragement offered through religious observance in the ghetto was influential especially for young survivors, many of whom would turn to an observant Jewish faith (Vynokurova 2010, 24).

In the larger ghettos of Poland and Germany, more is documented regarding how Jews viewed the holy days; similar hopes and difficulties surrounded Jewish holidays in Shargorod and other Transnistrian ghettos. Jean Améry, an Auschwitz survivor and a self-declared agnostic, argued that faith allowed people to transcend themselves and their reality. Those faithful to their religious traditions were not captives of their individuality-their own needs in the present time-but part of a spiritual continuity (Améry 1980, 14). Religious observance in the ghetto was an important part of communal life and of understanding one's identity as a Jew. It helped maintain a semblance of past joys and of hopes for the future.

Anna Ivankovitser, another local Shargorod survivor, remembered how they celebrated Pesach with a rabbi from Bukovina leading the Haggadah. They made matzah, the only traditional food available due to lack of resources. Anna wrote, "Of course this matzah was far from authentic matzo, but so was our life in the ghetto" (Ivankovitser 2002). Despite working together across religious, cultural, and social barriers, the feeling remained of being forced into an inauthentic living situation by the occupying authorities. This inauthenticity was overcome by those who put all their energies into helping those in need, especially the orphans.

The orphanage was another important place of cultural activity where young people were helped, as mentioned previously, regardless of place of origin. Rosa Levi of Suceava headed the Shargorod orphanage's activities and was remembered by survivors as a kind woman who created a homelike atmosphere. She ensured the orphans received the best possible healthcare, education, and training for various skills. Children put on plays with themes from their lives in the ghetto. They were taught Jewish history and Hebrew, among other subjects (Shachan 1996, 260; Teich 1958, 241). Others like Anna Ivankovitser learned German from the Bukovinan boyfriend she met in the ghetto (Ivankovitser 2002). There was reciprocity among the children in teaching language and sharing games and customs from their hometowns.

Marcu Rozen kept a small notebook from his time in the Shargorod orphanage and in an interview described with fondness the teachers and fellow orphans (Rozen 2004, 11). Children shared similar sufferings as well as hopes; it was in the orphanage that some made their first friends during the war. As the typhus epidemic had been indiscriminate with the parents of these children, those who survived the epidemic in the spring of 1942 also could not discriminate against the needy children.

Shargorod ghetto included Zionist activists, some of them from among the older orphans, who helped unite many in the ghetto under the common banner of emigration to Israel. Zionist youth secretly published a newspaper and were dedicated to educating the ghetto orphans. Similarly, in the Djurin ghetto, young people distributed a newspaper entitled Courier for a short time in 1943. In it were songs or poems that revealed the mix of Jews in the ghetto as well as articles describing social problems that arose from such a mix. One author claimed the ghetto was not a real community but a fictitious one (Litani 1963, 40-43; M. Sherff, "The Youth Movement in Shargorod," Masuah 4 [April 1976]: 212-214, quoted in Dobroszycki and Gurock 1993, 147-148). People hoped the situation would be temporary, and as repatriations to Romania began in 1943, they knew their living situation would change.

The inevitable disagreements regarding religious observance, schooling, youth movements, and other cultural activities due to different backgrounds as well as to fear of the authorities were nevertheless largely overcome in Shargorod due to the ghetto residents' dedication to working together to survive. By rallying around the orphans and participating communally in various 
religious and cultural activities, they reinterpreted their entangled notions of belonging and used regional particularities and advantages for the benefit of all.

Authorities stated that 240 Bessarabian Jews and 2,731 Bukovinian Jews were alive in Shargorod in 1943, while Teich surmised a survival rate of 70-80\% (Carp 1996, 207, 334, 457; Teich $1958,251)$. The exact number is disputed due to inadequate documentation by Romanian wartime authorities and the movement of Jewish deportee groups through the ghetto at different times during the war. Nevertheless, the institutions described in this article were crucial to the survival of Shargorod's remaining Jewish population at the end of the war.

\section{Conclusion}

The Shargorod ghetto was different from surrounding Transnistrian ghettos and from other ghettos in the west. Ghetto leaders were on better terms with the Romanian officials, whom they bribed; they also received more help from the local Ukrainian population, especially the local women whose husbands had been drafted into the Soviet army. The deportees managed to smuggle the Suceava Jewish community's funds into the ghetto. This not only protected the Suceava Jews, but also allowed for the development of the institutions that came to benefit the entire ghetto community. The soap factory, school, and orphanage were well organized and interregional. Good relations with the local population and the reciprocal support of ghetto inhabitants and partisans also provided protection (Baur 2014, 491). These could all be seen as a result of strong cooperation among Jews in the ghetto despite various origins.

Bessarabian survivor Avigdor Shachan claimed that the problem of deportees isolating themselves into communities of origin did not last long (Shachan 1996, 254). However, it lasted long enough to make Wilhelm Filderman address the situation in 1943 when the Autonomous Committee of Assistance in Bucharest began sending aid (Ancel 1986, vol. V, 390, 498). Shargorod Jews tried to overcome this dangerous tendency, and their leader Meier Teich received a more positive portrayal in postwar accounts than the Zmerinka ghetto's Herschmann or even Mogilev's Jagendorf.

Their ultimate appropriation of regional identity allowed for better cooperation and assistance among the diverse ghetto population. Those who put regional identity first faced grave moral questions, but they nevertheless benefitted from the inclusive institutions set up by the ghetto council. When struggling for survival, all inevitably faced difficult moral decisions, but how one identified themselves in such situations affected their course of action and how they were remembered. The difficult situation of the Jews in the Shargorod ghetto forced them to reappropriate and reinterpret their traditions and beliefs- the foundations of their identity-and thereby strengthen it. Assimilated and observant Jews reassessed what it meant to be Jewish and, though no new universal definition was proposed, they came to better understand what the Torah meant by the commandment to "love your neighbor as yourself" (Leviticus 19:18). At this time, the majority of Romanians, who claimed to be devout Orthodox Christians, seem to have forgotten the teaching of Jesus on this commandment in the Gospel of Mark 12:30-31.

The Romanian officials attempted to place a new identity on the Jewish deportees and locals: they were now Transnistrians, with no ties to Romania, Ukraine, or the Soviet Union (Doc. 40, Grilj et al 2013, 204-210). This identity never held ground and was rejected as people hoped to return to their hometowns or considered themselves simply, or not so simply, Jews. Romanian Jewish identity, as well as that of Ukrainian Jews, took different forms and varied from individual to individual-from complete assimilationists to Hassidim. In the Shargorod ghetto, when forced into survival mode by an all-inclusive Jewish identity imposed from above, one which some initially resisted, the deportees and local Jews achieved an admirable level of solidarity. Spurred by their common human identity (refused to them by Nazi-allied governments) they strove for survival across political, economic, religious, and cultural lines. 


\section{Notes}

1 These included Southern Dobrodja, which was ceded to Bulgaria during the war. Due to the scope of this essay, Dobrodja and northern Transylvania will not be discussed in detail since these regions were not under Romanian control for a significant part of the war.

2 However, local Jewish political and religious leaders remained the most important venues for acquiring aid and ensuring survival when the war began. Outside assistance was sought once these leaders exhausted their resources or were killed.

3 As a form of appeasement for giving Northern Transylvania to the Hungarian state, Transnistria came under the authority of Ion Antonescu and the Romanian government. The Germans also hoped it would solve the problem of Romanian authorities sending Jews east into German occupied land to be the sole responsibility of German forces. Romanian leaders' racial policy, unlike Germany's, wanted to cleanse the land of the Jewish minority and were not too concerned what Jews did in other countries. Under Romanian authority, both Romanian and German armies were responsible for exploiting the land and its inhabitants.

4 Transnistrian extermination camps in the Golta Region (Bogdanovka, Domanevka, and Akhmetchetkha) require separate analysis.

5 Ordinance number 23 required the displacement of Transnistrian Jews resulting in 2,000 local Jews remaning in Shargorod (compared with 3,733 who remained in the Moghilev ghetto).

6 Meier Teich: "În lupta pentru viață, pentru pâine, sau pentru un loc de odihnă, chiar în gunoi, omul devine un animal care scrâșnește din dinți față de cel ce trăiește alături și se apropie ca să-I dispute paine sau culcușul.”

7 According to the author of this letter, Shargorod had about 2,000 local Jews joined by 4,000 deportees by December 5, 1941.

8 Ietti spent time in the Transnistrian ghettos of Mogilev, Kopaigorod, Shargorod, and Peciora.

9 Reserve lieutenant Ion Bogza, unfortunately forgot on a train, on March 20, 1942, a suitcase with 363,500 Lei, sent by Jews in Dorohoi to those who had been deported to the Moghilev ghetto. Money sent to Transnistria from Jews in Romania rarely reached its destination, but what did arrive was used by the largest two ghettos of Mogliev and Shargorod.

10 During Bukovina's Hapsburg days, the region was a "conduit for transmitting all manner of ideas, goods, and people between central and eastern Europe," but David Rechter analyzes the extent to which the image of a prosperous and safe Bukovina for Jews was a myth.

11 A piece by Meier Teich entitled Channukkah in the Ghetto was published in Tel Aviv, but I have been unable to locate the source.

\section{References}

Altshuler, Mordechai. 2012. Religion and Jewish Identity in the Soviet Union, 1941-1964. Lebanon, NH: Brandeis University Press.

Altskan, Vadim. Spring 2012. "On the Other Side of the River: Dr. Adolph Herschmann and the Zhmerinka Ghetto, 19411944.” Holocaust and Genocide Studies 26 (1): 2-28.

Améry, Jean. 1980. At the Mind's Limits: Contemplations by a Survivor on Auschwitz and its Realities. Bloomington, IN: Indiana University Press.

Ancel, Jean. 1986. Documents concerning the Fate of Romanian Jewry during the Holocaust. New York: Beate Klarsfeld Foundation.

Ancel, Jean. 2011. The History of The Holocaust in Romania. Lincoln, NE: University of Nebraska Press and Yad Vashem.

Andrein. 2011. “Romania Mai 1942." https://commons.wikimedia.org/wiki/File:ROMANIA_MAI_1942.png\#file (Accessed July 31, 2017).

Arad, Yitzhak. 2009. The Holocaust in the Soviet Union. Lincoln, NE: University of Nebraska.

Baruch, Avital E.M. 2017. Frozen Mud and Red Ribbons: A Romanian Jewish Girl's Survival through the Holocaust in Transnistria and Its Rippling Effect on the Second Generation. Stuttgart, Germany: Ibidem Press.

Baur, Yehuda. 2014. "Jewish Resistance in the Ukraine and Belarus During the Holocaust." In Jewish Resistance against the Nazis, edited by Patrick Henry, 483-503. Washington, DC: The Catholic University of America Press.

Carp, Matatias. 1996. Cartea Neagra: Suferintele Evreilor din Români 1940-1944. Vol. III, Transnistria. Bucharest, Romania: Editura Diogene. 
Cîrstea, Marusia, Sorin Liviu Damean, and Doru Liciu. 2011. Istorie şi societate. Bucharest, Romania: Mica Valahie.

Cohen, Richard I., Jonathan Frankel, and Stefani Hoffman. 2010. Insiders and Outsiders: Dilemmas of East European Jewry. Oxford, UK: The Littman Library of Jewish Civilization.

Deletant, Denis. 2005. "Aspects of the Ghetto Experience in Eastern Transnistria." Ghettos 1939-1945 New Research and Perspectives on Definition, Daily Life, and Survival Symposium Presentations. Washington, DC: Center for Advanced Holocaust Studies, USHMM.

Dobroszycki, Lucjian and Jeffrey Gurock. 1993. The Holocaust in the Soviet Union: Studies and Sources on the Destruction of the Jews in the Nazi-Occupied Territories of the USSR, 1941-1945. Armonk, NY: M.E. Sharpe.

Dumitru, Diana. 2009. "Atitudinea Populației Ne-Evreieşti din Basarabia şi Transnistria Față de Evrei în Perioada Holocaustului: O Perspectivă a Supraviețuitorilor.” Holocaust. Studii şi Cercetări 2: 35-58.

Dumitru, Diana. 2016. The State, Antisemitism, and Collaboration in the Holocaust: The Borderlands of Romania and the Soviet Union. New York: Cambridge University Press.

Goldstein, Leon. 1993. “Thoughts on Jewish Identity.” In Jewish Identity, edited by David Theo Goldberg and Michael Krausz, 79-91. Philadelphia, PA: Temple University Press.

Grilj, Benjamin M., Sergij Osatschuk, Dmytro Zhmundyljak, eds. 2013. Schwarze Milch: Zurückgehaltene Briefe aus den Todeslagern Transnistriens. Innsbruck, Austria: StudienVerlag.

Iancu, Carol. 2008. "An Outstanding Example of Solidarity with the Jews Deported to Transnistria: The Case of Reserve Lieutenant Ion Bogza.” Studia Hebraica 8: 345-351.

Ivankovitser, Anna. 2002. Interview by Ella Levitskaya, June. http://www.centropa.org/biography/anna-ivankovitser (Accessed April 15, 2016).

Janowski, Maciej, Constantin Iordachi, and Balázs Trencsényi. 2005. "Why Bother About Historical Regions? Debates over Central Europe in Hungary, Poland, and Romania." East Central Europe 32 (1/2): 5-58.

Kermish, Joseph. 1986. To Live with Honor and Die with Honor! Documents from the Warsaw Ghetto Underground Archives. Jerusalem, Israel: Menachem Press.

Korber, Miriam. 2009. Interview by Cosmina Gușu, October 31. http://www.inshr-ew.ro/ro/marturii/162-interviu-miriamkorber-bercovici.html (Accessed May 3, 2016).

Leibovici, Ietti. 2008. Interview by Cosmina Guşu, July 7. http://www.inshr-ew.ro/media/interviuri/interviu-ietti-leibovici (Accessed May 10, 2017).

Levin, Don. 1995. The Lesser of Two Evils: Eastern European Jewry under Soviet Rule 1939-1941. Philadelphia, PA: Jewish Publication Society.

Litani, Dora. 1963. “An Underground Newspaper in Transnistria.” Yediot Yad Vashem 31: 40-43.

Meer, Simon. 2008. Interview by Cosmina Guşu, July 7. http://www.inshr-ew.ro/ro/marturii/223-interviu-simon-meer.html (Accessed April 25, 2017).

Ofer, Dalia. 1996. "Life in the Ghettos of Transnistria." Yad Vashem Studies 25: 229-274.

Ofer, Dalia. 2009. "The Ghettos in Transnistria and Ghettos under German Occupation in Eastern Europe: A Comparative Approach.” Beiträge zur Geschichte des NS 25: 30-53. Göttingen: WallsteinVerlag.

Ofer, Dalia. 2014. “'Three Lines in History?' Modes of Jewish Resistance in Eastern European Ghettos.” In Jewish Resistance Against the Nazis, edited by Patrick Henry, 366-392. Washington, DC: The Catholic University of America Press.

Petrovsky-Shtern, Yohanan. 2014. The Golden Age Shtetl: A New History of Jewish Life in East Europe. Princeton, NJ: Princeton University Press.

Resolutions of the 16th Zionist Conference. 1930. London, UK: Central Office of the Zionist Organization.

Rotenstreich, Nathan. 1993. "Identification and Identity." In Jewish Identity, edited by David Theo Goldberg and Michael Krausz. Philadelphia, PA: Temple University Press.

Rozen, Marcu. 2004. Holocaust sub Guvernarea Antonescu Date Istorice si Statistice Privind Evreii din România în Perioada 1940-1944. Bucharest, Romania: A.E.R.V.H.

Shachan, Avigdor. 1996. Burning Ice: The Ghettos of Transnistria. New York: Columbia University Press.

Solonari, Vladimir. 2010. Purifying the Nation: Population Exchange and Ethnic Cleansing in Nazi-Allied Romania. Washington, DC: Woodrow Wilson Center Press.

Teich, Meier. 1958. "The Jewish Self-Administration in Ghetto Shargorod." Yad Vashem 2: 219-254.

Tibon, Gali. 2016a. "Two-Front Battle: Opposition in the Ghettos of the Mogilev District in Transnistria 1941-44.” In Romania and the Holocaust: Events-Contexts-Aftermath, edited by Simon Geissbühler, 151-170. Stuttgart, Germany: Ibidem Press.

Tibon, Gali. 2016b. “Am I My Brother's Keeper? The Jewish Committees in the Ghettos of Mogilev Province and the Romanian Regime in Transnistria during the Holocaust, 1941-1944.” Dapim: Studies on the Holocaust 30 (2): $93-116$.

Trunk, Isaiah. 1972. Judenrat: The Jewish Councils in Eastern Europe under Nazi Occupation. New York: MacMillan.

Vago, Raphael. 1994. "Romanian Jewry during the Interwar Period." In The Tragedy of Romanian Jewry, edited by Randolph Braham, 29-57. New York: Columbia University Press.

Vynokurova, Faina. 2010. "Fate of the Bukovinian Jews in the Ghettos and Camps of Transnistria, 1941-1944: A Review of the Source Documents at the Vinnytsa Oblast State Archive." Holocaust and Modernity 2 (8): 18-26. 
Weisbuch, Simcha. 2007. "Shargorod.” In The Book of the Jews from Suceava (Shotz) and the Surrounding Communities, edited by Benzion Fuchs. Haifa, Israel: Teper Publishers Ltd. http://shotzer.com/zope/home/en/1/holocaust_he/ (Accessed July 31, 2017).

Weiss, Aharon. 1979. “The Relations between the Judenrat and the Jewish Police.” In Patterns of Jewish Leadership, edited by Israel Gutman and Cynthia Haft, 201-218. Jerusalem, Israel: Yad Vashem.

Zabarko, Boris. 2005. Holocaust in the Ukraine. London, UK: Vallentine-Mitchell.

Cite this article: Ploscariu, I. D. 2018. Institutions for survival: The Shargorod ghetto during the Holocaust in Romanian Transnistria. Nationalities Papers 47: 121-135, doi:10.1017/nps.2018.16 